\title{
Gastronomy Tourism - A Sustainable Alternative for Local Economic Development
}

\author{
Iulian Adrian SORCARU ${ }^{\star}$
}

\begin{tabular}{l}
\hline \multicolumn{1}{c}{ A R T I C L E I N F O } \\
\hline Article history: \\
Accepted March 2019 \\
Available online April 2019 \\
\hline JEL Classification \\
O10, Z32 \\
Keywords: \\
Gastronomy tourism, Economic \\
development, European Regions Of \\
Gastronomy, Inbound tourist flows
\end{tabular}

\begin{abstract}
A B S T R A C T
Gastronomy tourism recorded a continuous worldwide increase in recent decades, reflected both by the multitude of niche tourist offers and also by the emergence of the food websites and national and international institutions. In this context, the study aims to present the basic characteristics and importance of gastronomy tourism for local economic development, the profile of the culinary tourism consumer, as well as the evolution, the thematic map and the size of tourism flows in a few regions known as European Regions of Gastronomy, in which the actions and objectives undertaken at the local level have as main purpose the promotion of local gastronomy and traditions that increase the international tourism visibility and implicitly the local economic development.
\end{abstract}

(c) 2019 EAI. All rights reserved.

\section{Introduction}

Currently, traditional food is preserved mainly in rural regions, especially in ceremonial and festive food. In order to attract consistent tourist flows, restaurants include more and more products of the region's specific food model. In the last decade, Easter or Christmas tourist offers, in various tourist destinations, attract tourists by including a festive meal featuring abundance of local dishes.

Gastronomy is an important part of rural tourism, and gastronomy tourism is heavily promoted at fairs and festivals with this specific in Europe. Rural tourism has developed in recent years, both internationally and in Romania, due to its special valences, including the preservation of the environment, the preservation of local traditions and cultural values, by participating in the gastronomic activities of the locals.

Traditional authentic foods and drinks are undoubtedly real tourist attractions, being at the visitors' disposal throughout the year, without a high seasonality and without depending on weather. Even though, there are certain fruits or plants that are only used in certain periods of the year in fresh foods and drinks, more often foods and especially beverages can be preserved or kept for a long time before they are consumed. And let's not forget that traditional food is part of the authentic experience that more and more tourists are looking for these days.

UNWTO in collaboration with its Affiliate Member, MADISON MK, conducted in 2016 an online survey targeting UNWTO Affiliate Members including but not limited to, DMOs (Destination Management Organizations), educational institutions, marketing and consultancy firms, accommodation providers, the meetings industry, food and beverage providers and wineries to better understand the perspective of the private and public sectors on gastronomy tourism and its importance for a destination. The survey conducted was specifically aimed at gaining a deeper understanding of the current stance of different destinations with regard to gastronomy tourism, both from the point of view of the public and private sector; knowing their position and the degree of importance given to gastronomy tourism as an engine of development of the economy; and to know whether their promotion is part of current and future strategic objectives. It responds to the specific objectives: importance of gastronomy tourism, promotion and strategy, measurement of tourism experience, impact on the community / destination, as well as opinion of gastronomy tourism.

A total of 77 responses were received in which $67.5 \%$ of them were from Europe, $22 \%$ from the Americas, $7.8 \%$ from Asia and the Pacific and 2.6\% from Africa. The majority of respondents represented governmental departments (41.5\%) and not-for-profit organizations $(28.5 \%)$; as well as educational institutions $(15.5 \%)$ and private sector businesses $(14.5 \%)$.

The majority (87\%) of responding organizations believe that gastronomy is a distinctive and strategic element in defining the image and brand of their destination. The other $13 \%$ of respondents who answered alternatively selected VFR (visiting friends and relatives) as a main motive to visit their destination. 
With regard to the question of gastronomy being a driving force for tourism development, the average of the answers was 8.19 on a scale of 1 to 10 where 10 is "strongly agree" (http://cf.cdn.unwto.org/sites/all/files/pdf/gastronomy report web.pdf).

In general, the main reason why tourists decide to visit a destination is the cultural motive, with nature as the second reason and the gastronomy placing third, but more distanced from the previous two. The following five motivational factors are closer to each other as shown in figure 1, especially shopping and health.

Figure 1. The motivational factors for tourists in Latin America to visit a destination (source: UNWTO Survey On Gastronomy Tourism, 2016)

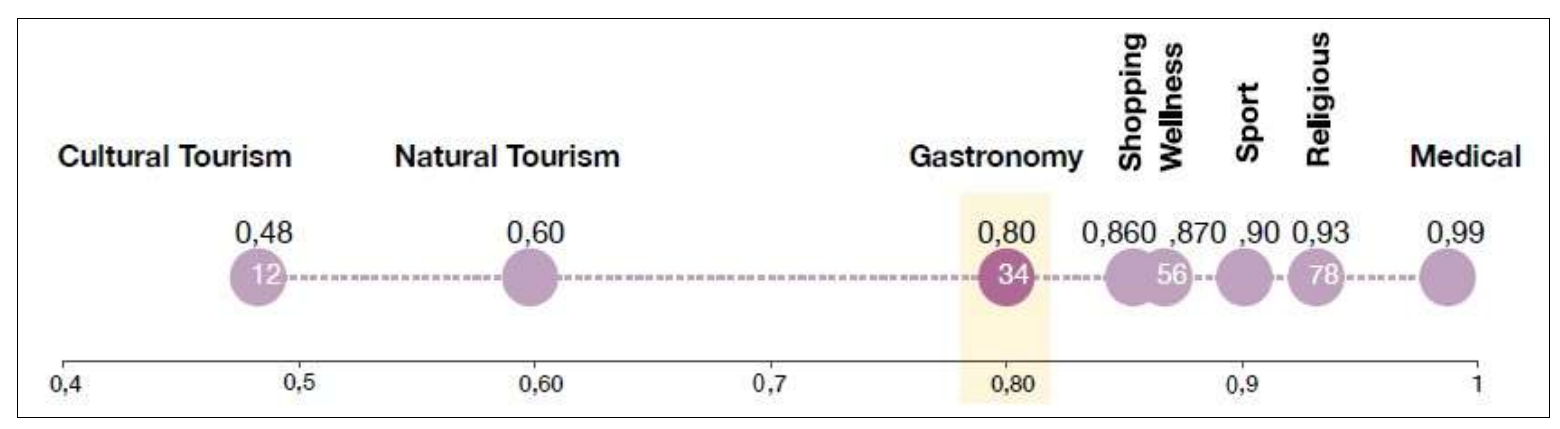

The World Food Travel Association (WFTA) defines culinary tourism as: the pursuit and enjoyment of unique and memorable food and drink experiences. For most tourist destinations, gastronomy plays a strategic role in their image and brand. Activities can range from tasting local food and drink to more adventurous and active experiences. Examples of culinary tourism activities include:

- cooking with locals

- cooking workshops

- $\quad$ eating at locals' homes, at local restaurants, or street food

- food and drink tasting sessions of cheeses, wines, beers, spirits etc.

- $\quad$ food and drink tours and trails

- collecting ingredients or participating in the local harvest

- $\quad$ visiting farms, orchards, wineries, distilleries, food markets, fairs or festivals

Culinary travellers are of all ages, but most are in the 30-60 age category. Based on the level of focus on food and drink, there are three types of culinary tourists:

\section{\# deliberate culinary tourist}

Around half of all culinary tourists are deliberate culinary tourists. These are generally people with a:

- higher socio-economic background

- middle to high income

- $\quad$ high interest in (food) culture

- $\quad$ strong desire to travel

- high interest in social and environmental issues

Experiencing and learning about local cuisine is their main travel purpose. They spend around 50\% of their holiday budget on culinary activities. This group appreciates the social side of food and drink. They like to interact with locals through their culinary activities, and are interested in authentic local food culture. Deliberate culinary tourists also care about the origins of their food and sustainability.

\section{* opportunistic culinary tourist}

About a quarter of culinary travellers are opportunistic culinary tourists. The members of this group enjoy experiencing local cuisine. They actively seek out culinary experiences, but have another primary reason for their trip. Relatively accessible culinary activities like visiting a market suit them well. They may also want to participate in more intensive activities that fit their plans. For instance, adventure travellers can try out adventurous culinary experiences. Adventure travel packages tend to be more popular if they include culinary experiences.

\section{\# accidental culinary tourist}

Another quarter of culinary travellers are accidental culinary tourists. They aren't considered 'serious' culinary tourists, like the other groups. These travellers don't seek out culinary activities: they participate simply because these activities happen to be available (https://www.cbi.eu/marketinformation/tourism/culinary-tourism). 


\section{Literature Review}

Almost all tourists, no matter the accommodations at which they are staying provide food and beverages services or not, prefer to eat outside; and get to know and taste the local dishes belonging to the region. Within this context, local dishes of a region have become important means to get to know and learn more about a different culture (Kastenholz \& Davis 1999; Gyimothy et al., 2000; Joppe et al., 2001). A tourist might want to visit an area to have some new cultural experience, or they just want to try local dishes and different tastes belonging to that area as well.

Figure 2. Triangle Concept of Indonesian Gastronomy (source: UNWTO Survey On Gastronomy Tourism, 2016)

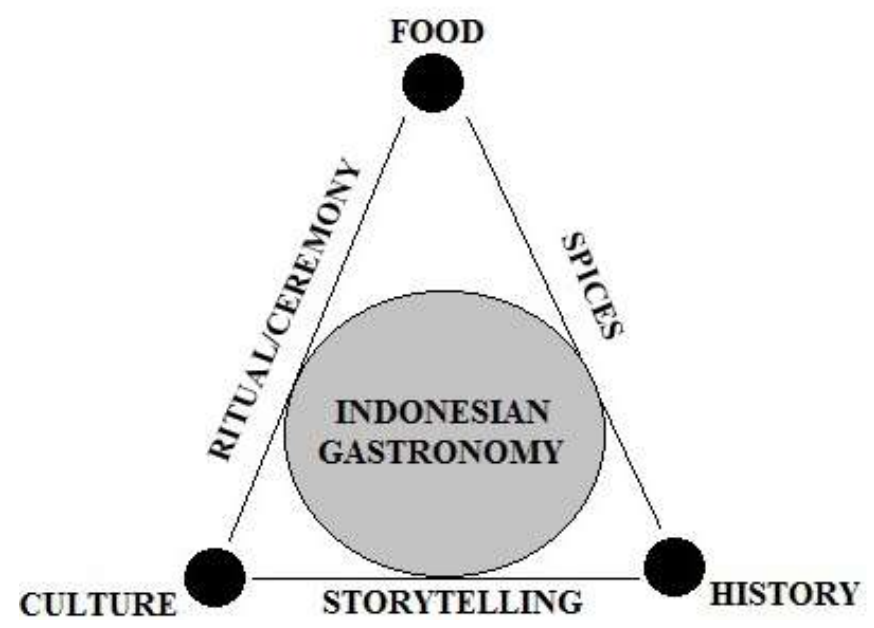

As a result of this, such reasons as trying local dishes of an area and observing production phases of and tasting a local dish which is made of a raw material available only in that specific region have now begun to be among the main reasons that affect tourists' preferences for destinations to visit. Moreover, this will contribute to the sustainability of the regions' resources and also to alternative tourism facilities that can be structured in regions with food culture coming into prominence (Yuncu, 2010). Gastronomy is now seen as a determinant factor in attracting tourists while they choose destinations. Gastronomic tourism can become an alternative tourism type on its own to sun and sea destinations, and it can also serve as an activity supporting these destinations (Kivela \& Crotts, 2006; Ulusoy, 2008).

Gastronomy is defined as the art of eating and drinking in many sources, being in fact an inter-related branch of art and science that has a direct relation with chemistry, literature, biology, geology, history, music, philosophy, psychology, sociology, medicine, nutrition, and agriculture (Kivela \& Crotts, 2006). As the topic is about eating and drinking, this covers such issues as nutritional sciences, sense of tasting and its physiology, wine production, functions of nutritional elements in human body, specifying qualities in choosing food stuffs, and developing production processes in accordance with hygiene and sanitation norms to prevent foods from going off physically, chemically, and biologically (Sormaz U., Akmese H., Gunes E., Aras S., 2016).

In tourism literature different terms like "culinary tourism", "gastronomy tourism", "gastro-tourism", "wine tourism", "food tourism", and "gourmet tourism" are used to define it. The widely used term is "gastronomic tourism", defined as "being in pursuit of unique experience of eating and drinking." Gastronomic tourism, which generally refers to the originality of a dish and its being indigenous to a place, a region or a country, covers the main areas of indigenous dishes and wine tourism (Hall \& Mitchell, 2005; Groves 2001, Green \& Dougherty, 2008).

Gastronomic tourism includes visiting food producers, eating festivals, restaurants and special places related to some special foods together with tasting a special dish, observing its production and preparation processes or eating a special dish from the hands of a very famous chef as well as seeing how a certain dish is being prepared (Hall et al. 2003; Hall \& Mitchell, 2005).

Gastronomic or food tours, arranged to introduce a region's dishes and food culture which play an important role in selection of and the experience tourists can have in a region, can feature a region. Some of these regions are France, Australia, South Africa, Italy, America, England, etc. where wine tourism is more developed; Canada with beer tourism, and Italy with such famous foods as pasta and pizza. Moreover, all these places together with Toscana region in Italy, Napa valley in California, The USA, South Africa, Australia, Champagne and Burgundy regions in Chile and France have been known to be gastronomy destinations for 
long years, also Turkey is famous for kebab and doner kebab (special dishes made from meat) (Charters \& Knight; 2002, Plummer et al., 2005; Getz \& Brown, 2006; McKercher et al., 2008).

Recently, the notorious website "tripadvisor" analyzed booking data (bookings, traveler reviews and traveler ratings) to determine the world's most popular foodie destinations and the experiences that are winning over travelers after they arrive. The results we present in table 1 show that Europe destinations are on the first positions of the top.

At the same time, among the famous international destinations, gastronomic tourism is beginning to grow in other less-known regions. Fortunately, Romania is among these regions, most of the foreign tourists, growing in recent years, appreciating "borșul pescăresc", "slănina afumată", "pârjoalele", "sarmalele în foi de viță or varză", "tochitura", "poalele în brâu", "papanașii", "mămăliga", "bulzul", "balmoșul", "palinca" and local wines: "Feteasca Neagra", "Muscat-Ottonel".

Table 1. The World's 10 Most Popular Foodie Destinations in 2018

(source: https://www.travelpulse.com/gallery/destinations/the-world-s-10-most-popular-foodie-destinations.html?image=1 )

\begin{tabular}{|c|c|c|c|c|}
\hline Rank & City & Country & Food Tour & Dishes \\
\hline 1. & Rome & Italy & $\begin{array}{c}\text { Rome Food Tour by Sunset around Prati } \\
\text { District }\end{array}$ & $\begin{array}{l}\text { buffalo mozzarella; } \\
\text { prosciutto with fig; } \\
\text { ricotta; } \\
\text { scamorza with spinach }\end{array}$ \\
\hline 2. & Florence & Italy & $\begin{array}{c}\text { Cooking Class and Lunch at a Tuscan } \\
\text { Farmhouse with Local Market Tour } \\
\text { from Florence by Walkabout Florence } \\
\text { Tours }\end{array}$ & $\begin{array}{l}\text { bruschetta; } \\
\text { roast pork; } \\
\text { tiramisu }\end{array}$ \\
\hline 3. & Paris & France & $\begin{array}{l}\text { Paris Secret Food Tour: Taste of } \\
\text { Montmartre }\end{array}$ & $\begin{array}{l}\text { baguette; } \\
\text { local cheese and } \\
\text { chocolate }\end{array}$ \\
\hline 4. & Barcelona & Spain & Interactive Spanish Cooking Experience & $\begin{array}{c}\text { Spanish tapas; } \\
\text { traditional paella; } \\
\text { sangria }\end{array}$ \\
\hline 5. & New Orleans & USA & $\begin{array}{l}\text { Destination Kitchen's gourmet walking } \\
\text { tour of the French Quarter }\end{array}$ & $\begin{array}{c}\text { Shrimp \& Mango Salad } \\
\text { with Tostones Cups; } \\
\text { Madeleines; } \\
\text { Bloody Mary } \\
\end{array}$ \\
\hline 6. & New York & USA & $\begin{array}{c}\text { "Best of Brooklyn" Half-Day Food and } \\
\text { Culture Tour }\end{array}$ & $\begin{array}{c}\text { pizza; } \\
\text { pierogi; } \\
\text { cannoli; } \\
\text { chocolate }\end{array}$ \\
\hline 7. & Venice & Italy & Cicchetti and Wine tour & $\begin{array}{l}\text { Venetian tapas; } \\
\text { Prosecco; } \\
\text { Spritz } \\
\end{array}$ \\
\hline 8. & Madrid & Spain & Gourmet Madrid Tours & $\begin{array}{l}\text { chickpea stew; } \\
\text { salted cod }\end{array}$ \\
\hline 9. & Tokyo & Japan & Tokyo By Night: Japanese Food Tour & $\begin{array}{c}\text { yakitori; } \\
\text { monjayaki; } \\
\text { wagashi }\end{array}$ \\
\hline 10. & Bangkok & Thailand & $\begin{array}{c}\text { The Bangkok Food Tour by Taste of } \\
\text { Thailand Food Tours }\end{array}$ & $\begin{array}{l}\text { som tam; } \\
\text { larb }\end{array}$ \\
\hline
\end{tabular}

\section{Objectives and Methodology}

In the context of a substantial increase of culinary tourism in the last decade, the possibility of practicing niche tourism activities that would generate additional income for local communities and, implicitly, increased competitiveness and economic development generated the emergence of European Regions Of Gastronomy. The major objectives of the study are:

$>$ presenting the methodology underlying the designation of an European Gastronomic region;

$>$ presenting the numerical evolution of the European Regions of Gastronomy and their main characteristics;

$>$ identifying and presenting the main projects which bring together the public sector actors, the business community and the non-governmental to capitalize the opportunities offered by 
ecotourism, rural tourism or gastronomy tourism that will generate local economic development in the gastronomic regions;

$>$ the evolution of tourist flows;

$>$ creating a map to reflect the current network of the European Regions of Gastronomy and its evolution.

The research was conducted based on the information provided by the relevant international institutions, such as UNWTO (World Tourism Organization), IGCAT (International Institute Of Gastronomy, Culture, Arts And Tourism), CBI (Centre for the Promotion of Imports from developing countries), WFTA (World Food Travel Association), but also on studies from the literature mentioned in the bibliography.

\section{Results And Discussion}

Prior to the emergence of European Regions of Gastronomy, we must mention the NGO that made it possible to create these regions, namely IGCAT.

IGCAT is a non-profit institute established in 2012 working with regional stakeholder consortiums in the fields of gastronomy, culture, arts and tourism. It counts on the expertise of a worldwide network of experts and works in partnership with specialised intergovernmental organisations. IGCAT aims to empower local communities by guiding, facilitating and supporting leaders in regions to understand the potential of their distinct food, culture, arts and sustainable tourism assets.

One of IGCAT's projects was the creation in 2014 of The European Region of Gastronomy Platform. This platform is opened to regions that declare a moral obligation to ensure improved food quality and support for local cultures/traditions and that are ready to capitalise on the growing convergence of food, culture, and tourism sectors and exciting transformations happening at a local level that could support regional development.

The first step the regions need to go through is to become members of the European Region of Gastronomy Platform for at least 5 years. By joining the Platform, the regions are given the opportunity to submit a dossier for the ERG Title, the IGCAT Expert Panel reviewing this file later.

So far, the platform has been joined by regions from ten countries, the series being opened by the Minho regions of Portugal and Catalonia in Spain in 2016.

In 2017 they were followed by Riga-Gauja region of Latvia, East Lombardy of Italy and Central Aarhus-Denmark, followed in 2018 by the North Brabant (Netherlands) and Galway (West Ireland).

Along with Sibiu in 2019, the title will also be owned by the South Aegean region of Greece. In 2020 the Kuopio region of Finland is already confirmed, and in 2021 the platform will be joined by no more than two regions (three being the maximum number of regions eligible to hold the title in one year) in Portugal (Coimbra) and Slovenia, their application files still being under evaluation.

Each of the above-mentioned regions aims to support communities and the local economy by organizing events to promote traditions, cultures and local cuisine to attract as many tourists as possible. Here, we can mention, the Galway Region (West Ireland), which stimulates local producers, SMEs to reinvent their food, thus eliminating the costs of exporting local products. Thus, the conclusion reached by the representatives of the region was that perhaps they should not focus so much on exports and convince as many tourists as possible to visit the region in order to enjoy the extraordinary traditional dishes. To this end, in 2018, Galway hosted the Food on the Edge conference, attended by top chefs from all over the world, with topics such as food security, tasting the local products (the famous lamb kept on the lavender bed and salty with sea salt).

Northern Brabant (Netherlands) also obtained the title of European Region of Gastronomy in 2018. The region that gave Van Gogh found a very innovative way to promote its culinary culture. In a former chapel, for 24 months, founded a pop-up restaurant called GAST, where 24 of the best chefs in the region had the opportunity to cook. The first chef, Soenil Bahadoer, awarded with two Michelin stars, offered a fivecourse culinary approach to Van Gogh's work, while works of the latter were projected on the walls of the church.

In 2019, Sibiu Region (Romania) aims to organize a series of programs to increase its notoriety of traditional dishes while contributing to increasing tourist attractiveness. Among these we mention:

$>$ The countryside fair - garden and landscape, a program promoting the homestead, from planning the garden for planting cereals, vegetables, orchards and grape-vines and collecting aromathic and medicinal herbs from the spontaneous flora, their description, modeling timedynamics while maintaining the resilience of local communities and their role for nutrition, trade, habitat. Every weekend, local communities and neighboring regions of Sibiu cook seasonal vegetables and meat (fish, mutton, beef, pork, chicken, duck) for the visitors. The program ends in December with the feast of Ignatius.

$>$ Invest In Sibiu, an international conference promoting busines opportunities in agriculture and connected fields. 
$>$ Sibiu Food Forum, a debate event including exchanges of best practices for presenting the experience of Sibiu in the European Region of Gastronomy platform, and presentations of the obtained results, aimed at ensuring the sustainability of the program.

> Animate ASTRA, an animation program of ASTRA Open Air Museum by the organization of gourmet workshops, crafting workshops, dances and songs and a student program for seeding the gardens of the museum with plants specific to the area of Sibiu, in the period April - October.

> Food tours, such as The Cheese Route in Mărginimea Sibiului, The Wine Route on Târnave, the Route of Transhumance and new culinary trips that will introduce visitors to the world of cultural landscapes shaped by agriculture, local tastes, craftsmanship of traditional agriculture, involving participants in the cooking sessions, tastings and gastronomic rituals. Circuits create connections between urban and rural touristic poles.

Figure 3. The Evolution Of European Gastronomic Regions (source: map made in ArcGis 10.1)

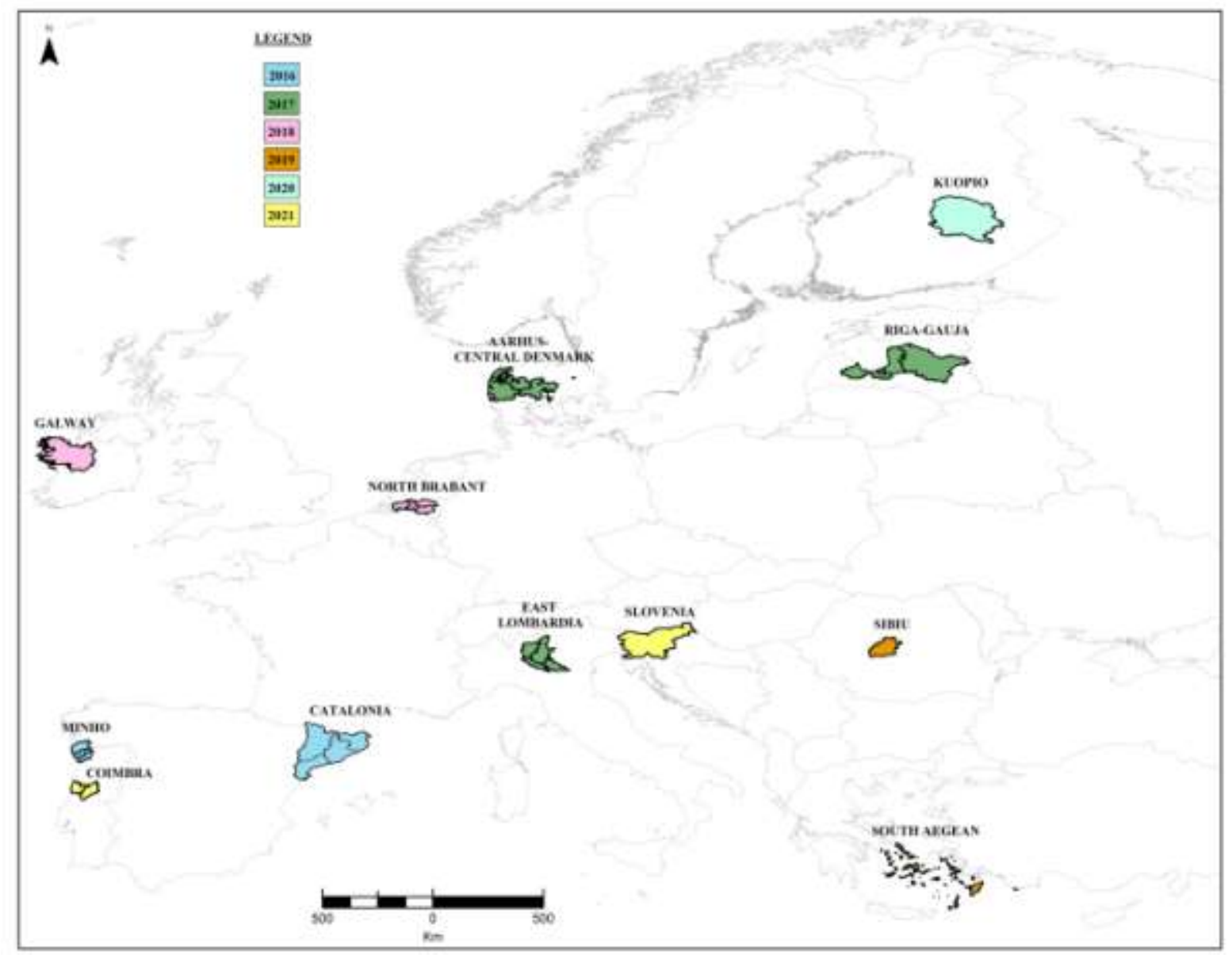

The evolution of the inbound tourist flows, due to the fact that many of the European Regions of Gastronomy have recently acquired this status (2016-2019) or will receive the title in the next two years (2020-2021), was achieved only for Minho and Catalonia Regions, according to the information provided by central or local statistical institutions in Portugal and Spain. According to tables 2 and 3, although there is no statistics centered exclusively on gastronomy - as a motivation for tourist travel - we can see a continuous increase of overnight stays in accommodation units (local and foreign tourists) in the Portuguese region between 2015-2017. In Catalonia, the data provided by the local statistical institute sums up only the foreign tourists who visited the region, the evolution being oscillating (although some data are missing from the statistics provided by IDESCAT), with an upward trend after 2016 (table 3). 
Table 2. Number of Nights in Tourist Accommodation Establishments by Geographic Localization and Place of Residence în Minho Region During 2015-2017

(source: www.ine.pt, statistical table extracted on February 01, 2019)

\begin{tabular}{|c|c|c|c|c|c|c|c|c|c|}
\hline \multirow{2}{*}{ Region } & \multicolumn{3}{|c|}{2017} & \multicolumn{3}{|c|}{2016} & \multicolumn{3}{|c|}{2015} \\
\hline & Total & Portugal & $\begin{array}{c}\text { Foreign } \\
\text { countries }\end{array}$ & Total & Portugal & $\begin{array}{c}\text { Foreign } \\
\text { countries }\end{array}$ & Total & Portugal & $\begin{array}{c}\text { Foreign } \\
\text { countries }\end{array}$ \\
\hline $\begin{array}{c}\text { Alto } \\
\text { Minho }\end{array}$ & 655006 & 397513 & 257493 & 544477 & 345643 & 198834 & 464316 & 285603 & 178713 \\
\hline Cávado & 889470 & 496235 & 393235 & 795627 & 464901 & 330726 & 672383 & 405398 & 266985 \\
\hline Ave & 465061 & 259003 & 206058 & 378228 & 214416 & 163812 & 346323 & 208695 & 137628 \\
\hline $\begin{array}{l}\text { Minho } \\
\text { (total) }\end{array}$ & 2009537 & 1152751 & 856786 & 1718332 & 1024960 & 693372 & 1483022 & 899696 & 583326 \\
\hline
\end{tabular}

Table 3. Foreign Tourists (thousands) in Catalunya by Reason Of Travelling During 2015-2017

(source: Institut d'Estadística de Catalunya)

\begin{tabular}{|c|c|c|c|}
\hline Motivation Factors & $\mathbf{2 0 1 5}$ & $\mathbf{2 0 1 6}$ & $\mathbf{2 0 1 7}$ \\
\hline Leisure and vacations & $15,596.9$ & $14,885.8$ & $16,092.9$ \\
\hline $\begin{array}{c}\text { Personal } \\
\text { (relatives, health and shopping) }\end{array}$ & 848.9 & $:$ & $:$ \\
\hline Professional reasons & $2,049.0$ & $1,682.6$ & $1,524.1$ \\
\hline Others & 765.9 & $1,570.7$ & $1,501.4$ \\
\hline Total & $\mathbf{1 9 , 2 6 0 . 6}$ & $\mathbf{1 8 , 1 3 9 . 2}$ & $\mathbf{1 9 , 1 1 8 . 4}$ \\
\hline
\end{tabular}

\section{Conclusions}

Although the data is insufficient to analyze the tourist movement, having as main motivation the local gastronomy, the studies quoted in the article and the ascending evolution of the inbound tourist flows in certain European regions that hold the title of "region of gastronomy" show a significant increase of tourist preferences for this form of tourism at international level.

This growth trend in gastronomy tourism is also being exploited by a number of regions less known among the world's tourist destinations for their natural or cultural attractions, but which have quickly become aware of local economic development opportunities by promoting local culinary and attracting foreign tourists.

Thus, the evolution of the network of European Regions of Gastronomy during 2016-2021 is edifying and the quantitative analysis of the tourist flows for the regions that have obtained this status after 2017, will be conclusive for the success of tourism activities that capitalize local gastronomy and gastronomy tourism.

\section{References}

1. Charters, S., Knight, J.A., (2002), Who is the wine tourist?, Tourism Management, 23(1); 311-319.

2. Getz, D., Brown, G., (2006), Critical success factors for wine tourism regions: a demand Analysis, Tourism Management, 27(1); 146- 158

3. Green, G.P., Dougherty, M.L. (2008). Local ising link ages for food and tourism: culinary tourism as a community development strategy.Community Development, 39(3); 148-158.

4. Groves, A.M., (2001). Authentic British food products: A review of consumer perceptions. International Journal of Consumer Studies, 25 (3); 246-254.

5. Gyimothy, S., Rassing, C., Wanhill, S., (2000), Marketing works: a study of restaurants on Bornholm, Denmark, International Journal of Contemporary Hospitality Management,12, 371-379

6. Hall, M., Mitchell, R., (2005), Gastronomic tourism: comparing food and wine tourism experiences, İcinde M. Novelli (Editor), Niche Tourism,Contemporary Issues, Trendsand Cases, ss. 89-100

7. Hall, M.C., Sharples, L., Mitchell, R., Macionis, N., Cambourne, B., (2003). Food tourism around the world: development, management and markets, Butterworth-Heinemann: Elsevier.

8. Joppe, M., Martin, D., Waalen, J., (2001), Toronto's image as a destination: a comparative importance satisfaction analysis by origin of visitor, Journal of Travel Research, 39,252-260

9. Kastenholz, E., Davis, D., Paul, G., (1999), Segmenting tourism in rural areas: the case of north and central Portugal, Journal of Travel Research, 37,353-363

10. Kivela, J., Crotts, J., (2006), Tourism and Gastronomy: Gastronomy's Influence on How Tourists Experience a Destination, Journal of Hospitality \& Tourism Research, 30: 354-377

11. McKercher, B., Okumus, F., Okumus, B., (2008). Food tourism as a viable market segment: it's all how you cook the numbers, Journal of Travel\& Tourism Marketing, 25,(2);137- 148. 
12. Plummer, R., Telfer, D., Hashimoto, A., Summers, R., (2005), Beer tourism in Canada along the water loo-Wellington aletrail, Tourism Management, 26, (3); 447-458

13. Sormaz U., Akmese H., Gunes E., Aras S. (2016), Gastronomy in Tourism, Procedia Economics and Finance 39 ( 2016 ) $725-730$

14. Ulusoy, B., (2008), Ulke mutfagı tarih ve kulturu ortaya cıkartır, Food in life, Tourism gastronomy and life magazine, v:3, İstanbul

15. Yuncu, H.R., (2010), Surdurulebilir turizm acısından gastronomi turizmi ve Persembe yaylası, Congress of AybastıKabatas 11, Ankara

***http://cf.cdn.unwto.org/sites/all/files/pdf/gastronomy report web.pdf

***https://www.cbi.eu/market-information/tourism/culinary-tourism

***https://www.travelpulse.com/gallery/destinations/the-world-s-10-most-popular foodiedestinations.html?image=1

***https://igcat.org/projects/region-of-gastronomy-award/european-region-of-gastronomy-platform/

***https://igcat.org/projects/region-of-gastronomy-award/european-region-of-gastronomy-platform/bid-books/

***https://www.worldfoodtravel.org/cpages/home

*** www.ine.pt

*** www.idescat.cat

*** www.tripadvisor.com 